\title{
Is The First Amendment Law?- A Reply to Professor Mendelson
}

\author{
Laurent B. Frantz*
}

$\mathrm{P}^{\text {ROFESSOR WALIACE MENDELSON has recently taken me to task }}{ }^{1}$ for my P criticism" of the Supreme Court's use of an ad hoc "balancing of interests" test in free speech cases. The argument over balancing tends to be one in which there is no meeting of the minds because the contending sides are arguing from opposite unspoken assumptions. Thus, I welcome Professor Mendelson's reply as tending to bring into clearer view some of the underlying questions that need to be asked and discussed, and I ask indulgence to put my rebuttal in the rather pedantic form of stating some of those questions, as they appear to ine, and giving my answers to them.

First, let us attempt to define the issue under discussion. The first amendment provides that "Congress shall nnake no law ... abridging the freedom of speech ...." Should a court, to determine whether this provision has been violated, "weigh" the "conflicting interests" involved in the particular case? ${ }^{3}$ If the court concludes that the interests served by the governmental action outweigh the free speech "interest" (or if it feels bound to defer to what it takes to be a legislative judgment to the same effect), is this sufficient to justify holding that action constitutional?

Here is one statement of the matter in an opimion for the Court by Justice Harlan:

Undeniably, the First Amendment in some circumstances protects an individual from being compelled to disclose his associational relationships. However, the protections of the First Amendment, unlike a proper claim of the privilege against self-incrimination under the Fifth Amendment, do not afford a witness the right to resist inquiry in all circumstances. Where First Amendment rights are asserted to bar governmental interrogation resolution of the issues always involves a balancing by the courts of the competing private and public interests at stake in the particular circnmstances shown. ${ }^{4}$

After discussing the issue thus defined, Justice Harlan concludes "that the balance between the individual and the governmental interests here at

* A.B., University of Tennessee, 1932 ; LL.B., University of Tennessee, 1935 ; LL.M., Duke University, 1950; Editor, Bancroft-Whitney Co., San Francisco.

1 Mendelson, On the Meaning of the First Amendment: Absolutes in the Balance, 50 CarrF. L. REv. 821 (1962).

2 Frantz, The First Amendment in the Balance, 71 YaLE L.J. 1424 (1962).

3 For an argument that it should, see Dennis v. United States, 341 U.S. 494, 517-46 (1951) (Frankfurter, J., concurring).

\& Barenblatt v. Umited States, 360 U.S. 109, 126 (1959). 
stake must be struck in favor of the latter, and that therefore the provisions of the First Amendment have not been offended." 5

Justice Frankfurter, in another opinion for the Court, put it this way:

[W] agree that compulsory disclosure of the names of an organization's members may in certain instances infringe constitutionally protected rights of association ... [citations] .... But to say this much is only to recognize one of the points of reference from which analysis must begin. To state that individual hiberties may be affected is to establish the condition for, not to arrive at the conclusion of, constitutional decision. Against the impediments which particular governmental regnlation causes to entire freedom of individual action, there must be weighed the value to the public of the ends which the regulation may achieve. ${ }^{6}$

It should be noted that the first of these statenients is directed only to a single class of cases, those in which first amendment rights are asserted "to bar governmental interrogation." It does not say or suggest that ad hoc balancing is a proper approach in all free speech cases. The statement by Justice Frankfurter, however, does seem to suggest this broader view, and he has indicated elsewhere that this is his position. ${ }^{7}$

The Court has thus far not conmitted itself to the theory that balancing applies to all free speech cases. Indeed, since the balancing vogue began, it has upheld free speech claims in at least four instances without any overt resort to ad hoc balancing. ${ }^{8}$ The balancing cases-or at least those in which it has been intimated that a governmental action, which would otherwise

5 Id. at 134.

${ }^{6}$ Communist Party v. Subversive Activities Control Bd., 367 U.S. 1, 90-91 (1961). In Dennis v. United States, 341 U.S. 494, 510 (1951), the test was said to be "whether the gravity of the 'evil,' discounted by its improbability, justifies such invasion of free speech as is necessary to avoid the danger." While this was put forward as an interpretation of the "clear and present danger" test, it seems rather to transform that test into a balancing test, since it completely eliminates the requirement that "force" nuust be "very likely to follow an utterance before there is a chance for counter-argument to have effect . ..." Am. Communications Ass'n v. Douds, 339 U.S. 382, 395 (1950). See also Whitney v. Califorma, 274 U.S. 357, 377 (1927) (Brandeis, J., joimed by Holmes, J., concurring). The Dennis formulation, however, differs from the later version of "balancing" in that it does require "danger." The competing interest to which first amendment rights are subordinated might, of course, be the need to avert a danger, but the terms in which the ad hoc balancing test is formulated do not require that it must be. And note Justice Frankfurter's reference to "the value to the public of the ends which the regulation may achieve." It is interesting that the Court has never found a second independent application for the test of the "gravity of the evil, discounted by its improbability." When the Court next used a clear and present danger approach, first in substance in Kingsley Int'I Pictures Corp. v. Regents of the Univ. of N.Y., 360 U.S. 684 (1959), and then explicitly in Wood v. Georgia, 370 U.S. 375 (1962), it restored the pre-Dennis version, justifying suppression only when there is no time for counter-argument.

7 Dennis v. United States, 341 U.S. 494, 517-46 (1951) (Frankfurter, J., concurring).

8 Edwards v. South Carolina, 372 U.S. 229 (1963); Wood v. Georgia, 370 U.S. 375 (1962); Tally v. Califorma, 362 U.S. 60 (1960); Kingsley Int'I Pictures Corp. v. Regents of the Univ. of N.X., 360 U.S. 684 (1959). 
have been forbidden, may be immunized from constitutional objection by such a balancing rationale ${ }^{9}$ - have all dealt with freedom of association. ${ }^{10}$ Indeed, all but one of them ${ }^{11}$ have dealt with the effect of a conpelled disclosure of membership or other association on the freedom to associate for the advancement of causes.

Suggestions that ad hoc balancing is appropriate only for a particular class of cases appear in the opinions. Thus, Justice Harlan apparently regards it as applicable only to "general regulatory statutes, not intended to control the content of speech, but incidentally limiting its unfettered exercise ...." 12 And Chief Justice Vinson had previously declared it to be the test "when particular conduct is regulated in the interest of public order, and the regulation results in an indirect, conditional, partial abridgment of speech ...."13

In this article, I am not discussing whether balancing is or is not an appropriate method for special classes of cases, such as those dealing with a non-discriminatory regulation of the time, place, and manner of speech, or those in which a statute aimed at conduct indirectly affects speech. Nor am I discussing whether the judge should examine the pros and cons before

9 The Court had earlier applied a sort of balancing to the situation where the governmental action, though having no tendency to control the content of speech, cuts off an otherwise available means for reaching the public with various messages. Schneider v. State (Town of Irvington), 308 U.S. 147 (1939) (ordinance prohibiting handbill distribution). Balancing was applied here, however, for the opposite purpose, viz, to give the legislative judgment less weight than in the case of "regulation directed at other personal activities." Id. at 161. This is more fully discussed in my previous article, sutpra note 2, at 1425-31. See also Konigsberg v. State Bar, 366 U.S. 36, 68-70 (1961) (Black, J., dissenting) ; Barenblatt v. United States, 360 U.S. 109, 142 (1959) (Black, J., dissenting).

10 So far, the cases in which the balance has been struck in favor of the first amendment interest have all dealt with freedon to associate for the advancement of racial equality: Gibson v. Florida Legislative Investigation Comm., 372 U.S. 539 (1963) ; N.A.A.C.P. v. Button, 371 U.S. 415 (1963) ; Bates v. Little Rock, 361 U.S. 516 (1960); N.A.A.C.P. v. Alabama, 357 U.S. 449 (1958). See also Louisiana v. N.A.A.C.P., 366 U.S. 293 (1961); Shelton v. Tucker, 364 U.S. 479 (1960), Doubtless this is a coincidence. See N.A.AC.P. v. Button, supra, at $444-45,448$ (dissenting opinion). So far, the cases in which a first amendment interest has been recognized as present, but subordinated to a competing interest found weightier, have all dealt with Communist associations, or other associations suspected of being "subversive." Communist Party v. Subversive Activities Control Bd., 367 U.S. 1 (1961); In re Anastaplo, 366 U.S. 82 (1961); Konigsberg v. State Bar, 366 U.S. 36 (1961); Braden v. United States, 365 U.S. 431 (1961); Wilkinson v. United States, 365 U.S. 399 (1961); Barenblatt v. United States, 360 U.S. 109 (1959); Uphaus v. Wyman, 360 U.S. 72 (1959). The Court has clearly indicated that this is no coincidence. Gibson v. Florida Legislative Investigation Comm., supra at 547-50; Barenblatt v. United States, supra at 128.

11 N.A.A.C.P. v. Button, supra note 10.

12 Komigsberg v. State Bar, 366 U.S. 36, 50 (1961). This statement fails to take account of the de facto balancing done in Dennis, in which the statute was not of the character to which Justice Harlan refers. See note 6, supra.

13 American Communications Ass'n v. Douds, 339 U.S. 382, 399 (1950). 
defining the scope of a constitutional guarantee. ${ }^{14} \mathrm{I}$ am discussing the view that the first amendment does not prohibit any action that the Court (whether deferring to a legislative judgment or applying its own) finds to be justified on an $a d$ hoc balancing basis. It is not my contention that the courts should never balance. My contention is that they should not, especially in free speech cases, enploy balancing as a substitute for an effort to find a rule or principle that can guide decision. Balancing, in other words, is not acceptable as the principle. It is acceptable (and doubtless inevitable) as the technique for making a purely prudential choice between alternatives that are, in principle, equally permissible.

Though general ad hoc balancing has not been adopted by the Court, a discussion of it is not purely academic. It has been adopted by Justice Frankfurter ${ }^{15}$ who, before his retirenient, was the senior and apparently most influential judicial advocate of balancing. And Professor Mendelson, when he undertakes to defend balancing, does not do so on the basis of considerations peculiar to the special class of cases in which the Court has applied it. His argunients are directed to the meaning-or lack of meaning-of the freedom of speech clause and to general considerations of the proper role of courts in applying constitutional limitations. If theories justifying balancing on so broad a basis should ultimately prevail, the result could only be a first amendment devoid of any higher level judgment to which an ad hoc balancing judgment could be subordinated. With this in mind let us turn to Professor Mendelson's argument and to the questions that it seems to me to raise.

IS $A D$ HOC BALANCING REQUIRED BY THE AMBIGUITY OR VAGUENESS OF THE FREEDOM OF SPEECH CLAUSE?

In support of the Supreme Court's balancing position, Professor Mendelson contends "that the language of the first amendment is highly ambiguous, and that this ambiguity is at best compounded by history." $10 \mathrm{He}$ apparently admits that "Congress shall make no law" is comprehensible as far as it goes, and he does not profess to be hopelessly puzzled by "abridging." But the amendment does not define "the freedom of speech," and Professor Mendelson quotes Professor Chafee ${ }^{17}$ to the effect that "the

14 Justice Black took this approach in Talley v. California, 362 U.S. 60 (1960) (social values of anonymous publication, and dangers of deterring expression of controversial views by requiring identification of proponents, taken into consideration in determining whether first amendinent protects right to publish anonymously). My reasons for regarding balancing in the process of definition as fundamentally different from ad hoc balancing are set forth at length in my previous article, supra note 2, at 1434-35.

15 Dennis v. United States, 341 U.S. 494, 517-46 (1951) (Frankfurter, J., concurring).

16 Mendelson, supra note 1 , at 821 .

17 Id. at 821,823 . 
framers had no very clear idea as to what they meant" by this phrase. Without a definition of "the freedom of speech," Professor Mendelson can make nothing of the statement as a whole, since "its cham of meaning cannot transcend the fogginess of its weakest link." ${ }^{18}$ Accordingly, he takes the view that the courts should set the text aside as incapable of shedding any light on how specific cases should be decided, and approach free speech issues on a pragmatic case-to-case basis. ${ }^{19}$ The constitutional text, without which courts would presumably have no authority to decide the case at all, should play no part in their decision.

Constitution writing is not a practicable undertaking if mexplicitness is to be treated as a total failure to say anything. Failure to define the key tern has not proved an insuperable obstacle to applying other constitutional provisions. The Constitution prohibits "unreasonable searches and seizures" without saying what kinds are reasonable. It prohibits "excessive bail" without saying anything about the level that should not be exceeded. It guarantees "speedy" trial without telling us how to decide what delays are permissible (indeed, it is entirely possible that the framers "had no very clear idea as to what they meant" by "speedy" trial). It provides that private property shall not be "taken for public use, without just compensation" without telling us what constitutes a taking, or what uses are "public," or what standards conpensation must meet in order to be called "just." Yet with all these clauses, it has been found possible to give the undefined key word some meaning (not necessarily "clear" meaning) and to treat that meaning as a mandatory standard for the disposition of those cases to which it is found to apply. ${ }^{20}$ Surely it is reading the freedom of

$18 \mathrm{Id}$. at 821 .

$19 \mathrm{Id}$. at $825-26$.

$20 \mathrm{It}$ may be noted that the meaning of constitutional provisions conferring powers may also turn on undefined key terms. For instance, Congress is granted power "to regulate commerce ... . among the several states." We are not told what "regulate" means, or what constitutes "commerce," or whether "among" means "between" or "throughout." Yet presumably Professor Mendelson would not argue that, because we cannot tell from the language exactly what power is conferred, the clause should not be deemed to confer any power-or should be treated as conferring only such powers as the Court, on a case-to-case pragmatic basis, decides Congress ougbt to have.

Furthermore, several constitutional provisions have been held to mean more than they explicitly say. "No person ... shall be compelled in any criminal case to be a witness against himself" (emphasis added) does not explicitly say that a witness in a civil case or a legislative investigation has any protection. Yet all the justices seem to be agreed that, in this respect at least, the clause means more than it says. "[N]or shall any person be subject for the same offence to be twice put in jeopardy of life or limb" does not explicitly say that there is any constitutional protection against second jeopardy as to imprisonment, yet no one doubts that there is. "Congress shall make no law respecting an establishment of religion" might mean no more than that Congress may not, by statute, designate one particular sect as our official national rehigion. The justices are not agreed as to what it means, but none of them demands that it should be himited to its minimum possible meanimg. 
speech clause with a scepticism verging on open hostility to say that no prohibitory content can be found im it, simply because, literally read, it may seem to prohibit too much! ${ }^{21}$

How are the vague and undefined words of the constitution ordinarily given content? Partly by an exercise of judicial judgment, certainly, but not ordinarily by an unprincipled case-to-case pragmatic judgment, unrelated to any concept of the meaning or function of the constitutional language. Nor is it enough to inquire what applications of the language would have been thought proper at the tine of its adoption. ${ }^{22}$ Constitutional limitations, no less than constitutional grants of power, need to be kept flexible enough to be applied to changed conditions and new problems. ${ }^{23}$ The starting point, in any such inquiry, should be to ascertain the purpose of the grant or prohibition. ${ }^{24}$ Once that has been done, a principled basis is generally found for deciding whether particular cases fall within the general language-as well as for extending the language to problems and conditions which the framers could not have foreseen, but which can nevertheless be recognized as within the goals we think they sought to achieve, or as exaniples of the evil we think they sought to guard against. ${ }^{25}$

Does the freedom of speech clause have a purpose? Professor Mendelson considers the regulation of speech to be indistinguishable, both constitutionally and in principle, from the regulation of action. ${ }^{26}$ So I suppose he must also believe that the right to say what one thinks is merely a special

21 Compare the "ex post facto" clause, which could be read in the same spirit as prohibiting any law with any kind of retroactive effect, yet the courts have not found it impossible to give some intelligible content to it.

22 Compare Brown v. Board of Education, 347 U.S. 483, 492 (1954) (in detcrmining whether equal protection clause prohibits school segregation, Court "cannot turn the clock back to 1868 when the Amendment was adopted . . . ."); Gompers v. Unitcd States, 233 U.S. 604, 610 (1914) (Holmes, J.) (significance of constitutional provisions "to be gathered by considering their origin and the lime of their growth").

23 See Reich, Mr. Justice Black and the Living Constitution, 76 HARv. L. REv. 673 (1963), especially at $742-44$.

24 For instances where the Court has looked to purpose to shed hight on otherwise ambiguous constitutional language, see McGowan v. Maryland, 366 U.S. 420, 442 (1961); Everson v. Bd. of Education, 330 U.S. 1, 14-15 (1947); Cramer v. United States, 325 U.S. 1, 31 (1945) ; Umited States v. Classic, 313 U.S. 299, 315-18 (1941); United States v. Miller, 307 U.S. 174, 178 (1939); Maxwell v. Dow, 176 U.S. 581, 602 (1900); Prigg v. Pennsylvania, 41 U.S. (16 Pet.) 539, 610-12 (1842) ; Craig v. Missouri, 29 U.S. (4 Pet.) 410, 431-32 (1830); Gibbons v. Ogden, 22 U.S. (9 Wheat.) 1, 188-89 (1824).

25 [I]n determining whether a provision of the Constitution apphes to a new subject matter, it is of hittle significance that it is one with which the framers were not familiar. For in setting up an enduring framework of government they undertook to carry out for the indefinite future and in all the vicissitudes of the changing affairs of men, those fundamental purposes which the instrument itself discloses.

United States v. Classic, 313 U.S. 299, 316 (1941) (Stone, J.).

28 Mendelson, supra note 1 , at 824-25. 
instance of every individual's freedom to do as he pleases-and subject to limitation for the general good on the same principles and to the same extent. ${ }^{27}$ If this is his standpoint, it is no wonder he finds the freedom of speech clause as imcomprehensible as I should find a provision forbidding Congress to abridge "the freedom of action." It also follows, of course, that had the framers held this view, there would have been no freedom of speech clause.

If the Constitution is viewed as adopting representative government as a device by which the people are to govern themselves, a significant function of the freedom of speech clause is at once apparent. The device calls for reciprocal government; for the people to govern the delegated authority by which they are governed. This cannot work unless there is an independent popular concensus, protected from governmental intervention, to which the delegated authority can be held responsible. If the delegated authority is permitted to prescribe what may and may not be advocated, especially in the realm of political theory and policy, then, pro tanto, it is no longer responsible to a popular will independent of its own, but to a reflection or extension of its own will. The people can still select, at the ballot box, those by whom they are to be governed, but they can no longer govern through them. The government may still be representative in form, but self-government is not its substance.

If the freedom of speech clause is conceived to serve this function, there is no difficulty about finding meaning in it. ${ }^{28}$ It still does not have the "clear meaning" that Professor Mendelson deinands of it, but constitutional provisions seldom have "clear meaning" and I suspect that they would not prove continuously serviceable for generations and centuries if

27 Note the ease with which Justice Frankfurter equates constitutionally protected freedom of association with "entire freedom of individual action" in text accompanying note 6 supra.

$28 \mathrm{My}$ view that this is the principal function of the freedom of speech clause and hence the best key to its meaning is, of course, adapted from Professor Meiklejohn. See, MEIkIEJOHN, Political Freedom: The Constitutional Powers of the Peopie (1960). I do not mean to imply that it would be improper to regard it as also serving other functions. For an excellent discussion of the functions of freedom of speech in a democratic society, see Emerson, Toward a General Theory of the First Amendment, 72 YALE L.J. 877, 878-86 (1963). Some of these other functions might require extending first amendment protection to situations where the strict Meiklejohn analysis, taken by itself, would not require its application. I have not attempted to discuss this because my purpose is not to state the full extent of the first amendment's meaning, but simply to answer a contention that no usable meaning can be found in it. Furthermore, I have not attacked halancing to put forward my alterative. I have put forward an alternative to balancing because I do not know how else to answer the balancers' insistence that there is no alternative. Nevertheless, there are others. One is the approach put forward in Emerson, supra. Another would be a return to the pre-Dennis version of "clear and present danger." For reasons that I will attempt to make clear in later sections of this article, I am convinced that any definition of "the freedoin of speech" that the Court could be persuaded to adopt, or even give serious consideration to, would be vastly preferable to $a d$ hoc balancing. 
they did $^{29}$ Borderline cases, and mixed cases, can still be put, which may require not only an exercise of judgment, but a very difficult one. But if meaning is attributed to the freedom of speech clause, those cases will not have to be approached without reference to a primciple, as Professor Mendelson apparently proposes that all free speech issues be approached.

Although according the freedom of speech clause a function does not do away with the difficult cases, it does, I think, create some easy ones. From this point of view, it becomes obvious that most of the cases that are supposed to confound the "absolutist"- - such as the man who falsely shouts "Fire!" in the crowded theater, the man who uses speech to solicit a crime, and the man who uses speech to enrich himself by fraudulent representations-are not cases in which it has been found necessary to abridge "the freedom of speech" for the protection of some "competing interest." They are cases in which, though speech is involved, "the freedom of speech" is not. It is also obvious, I think, that mere regulations of the time, place, and manner of speech-such as protecting the citizen's ears against sound trucks making "loud and raucous noises," ${ }^{30}$ or protecting his privacy against unwanted doorbell pushers, ${ }^{31}$ or prohibiting child labor on the streets whether or not engaged in the sale of religious pamphlets ${ }^{32}$-do not, per se, affect the "freedom" of speech. They may do so, however, if they are applied in a discriminatory manner so as to burden one point of view more than another, or if they are left open to discretionary application by officials who are empowered to use them as an instrunent for regulating the content of public discourse, or if they are carried to such an extent that adequate low-cost means of reaching the public with all points of view are no longer available.

Of course, all the above determinations can be stated in balancing terms, because, uuless a "competing interest" were present, government would have no occasion to act, even where there was no constitutional inhibition against such action. But it is not the presence or the weight of the competing interest that is deterninative. It is not even the nature of the speech in which the individual desired to engage (which would require an opposite determination in the case of the child selling religious pamphlets on the streets). The crucial factor is that the nature of the governmental action

20 The nature of a constitution requires "that only its great outlines should be marked, its important objects designated, and the minor ingredients which compose those objects be deduced from the nature of the objects themselves." McCulloch v. Maryland, I7 U.S. (4 Wheat.) 316, 407 (1819). Though Chief Justice Marshall's argument is directed to constitutional powers, it seems to me equally applicable to constitutional himitations. See also, In the Matter of Strauss, 197 U.S. 324, 330 (1905) (words in a constitution "are presumed to have heen used in a broad sense, with a view of covering all contingencies").

30 Kovacs v. Cooper, 336 U.S. 77 (1949).

31 Breard v. Alexandria, 341 U.S. 622 (1951).

32 Prince v. Massachusetts, 321 U.S. 158 (1944). 
was not such as to compromise or threaten the independence of that popular consensus to which the delegated authority must be held responsible. ${ }^{33}$

- It seems to me that a functional approach to the freedom of speech clause also suggests some clear cases of violation of that clause. I submit that it is not a borderline case when Communists are prosecuted, not for overt preparations for insurrection, not even for uttering or writing specific words of an insurrectionary nature, ${ }^{34}$ but for "conspiring" to spread a po-

38 The apparently willful blindness of the anti-absolutist to the fact that regulations which may impinge on speech are of different kinds, which may be quite different in their effect on its "freedom," is sometimes almost unbelievable. This is considered further infra in connection with the problem of "absolutes."

34 No Communist has ever been prosecuted under the Smith Act for the substantive offense of advocating violent overthrow. True, Justice Harlan, in Yates v. United States, 354 U.S. 298, 323-24 (1957), speaks of the Dennis case as involving advocacy that had already taken place, but Justice Harlan was not a member of the Court when Dennis was decided and I submit that his statement is historically inaccurate. The indictment in Dennis contained nothing to indicate that it was charged that advocacy of violent overthrow had already taken place. See 9 F.R.D. 367, 374-75. See also 102 F. Supp. 87-102, where the Dennis and original Yates indictments are printed in parallel columns. Compare Gitlow v. New York, 268 U.S. 652 (1925) in which the statement charged as a violation was set forth verbatim in the indictment. Judge Medina, in his charge to the jury, told them that it was not charged that the defendants personally advocated violent overthrow, nor that the Commumist Party as such did so. United States v. Foster, 9 F.R.D. 367, 376 (S.D.N.Y. 1949). And he also told then that the defendants might be convicted though the "objects of the conspiracy" (which included sucb advocacy) "were never accomplished." Id. at 378. There were two opmions in the court of appeals, totaling 31 pages. United States v. Dennis, 183 F.2d 201 (2d Cir. 1950). There were five opinions in the Supreme Court, totaling 98 pages. Dennis v. United States, 341 U.S. 494 (1951). No one of the seven opmions quotes a single statement as an illustration of advocacy of violent overthrow that had already taken place, or refers to any specific occasion on which such a statement was allegedly made. Justice Black, in his dissenting opimion stated that the defendants "were not even charged with saying anything or writing anything designed to overthrow the government. The charge was that they agreed to assemble and to talk and publish certain ideas at a later date." $I d$. at 579. None of the three opposing opinions undertook to refute that characterization of the charge. Of course, the content of a speech not yet written can be inferred, if at all, only from present opinions. And a prosecution for a conspiracy to engage in future advocacy is therefore a trial, not of speech, but of thought.

It should be noted that the Court said in Yates:

But when it comes to Party advocacy or teaching in the sense of a call to forcible action at soine future time we cannot but regard this record as strikingly deficient. At best this voluminous record shows but a half dozen or so scattered incidents which, even under the loosest standards, could be deemed to show such advocacy. Most of these were not connected with any of the petitioners, or occurred many years before the period covered by the indictment.

Yates v. Umited States, 354 U.S. 298, 329-30 (1957) (Emphasis added).

The record in Yates consisted of some 14,000 typewritten pages, id. at $327 \mathrm{n} .34$, and the evidence presented by the prosecution was closely modeled on that previously given in Dennis. In fact the Dennis defendants were named as co-conspirators in the Yates indictment and it was the prosecution's theory that both cases dealt with the same conspiracy. Justice Clark, in his Yates dissent, id. at 345-46, noted that the evidence in the two cases was closely parallel and that he thought the evidence in Yates was "equally as strong." So it is highly probable that the Dennis record would have been found "strikingly deficient" in the same way, had the Court analyzed the evidence, as it did in Yates. 
litical theory and doctrine capable of inspiring insurrection on some remote hypothetical future occasion. ${ }^{35}$ It is not a borderline case when persons are prosecuted merely for being members of an organization with knowledge that it holds such theories. ${ }^{36}$ It is not a borderline case when a Subversive Activities Control Board is set up to try and condemn associations, not for illegal activities, but for their political coloration. ${ }^{37}$ And-though the framers could not have foreseen such a development-there could be no clearer violation of the intended relationship between the sovereign principal and the delegated authority than for the representatives to summon a citizen before them and demand an accounting of how he has exercised his reserved powers. In fact, I cannot help wondering if perhaps Professor Mendelson's real difficulty is not so much the first amendment's ambiguity as the clarity with which it speaks to the heart of current controversy if it is permitted to mean anything.

DOES THE CASE AGAINST THE JUDICIAL "ACTIVISM" PRECLUDE TREATING THE FIRST AMENDMENT AS LAW?

In my original article, I stated that, though I did not propose to review the arguments for and against judicial review, I thought the evidence was "reasonably clear that the first amendment was proposed with the express expectation and intention that the courts would enforce it." 38 In support of this view I cited the familiar statement made by Madison in presenting the proposed Bill of Rights to the Congress:

If they are incorporated into the Constitution, independent tribunals of justice will consider themselves in a peculiar manner the guardians of those rights; they will be an impenetrable bulwark against every assumption of power in the Legislative or Executive; they will be naturally led to resist every encroachment upon rights expressly stipulated for in the Constitution by the declaration of rights. ${ }^{39}$

But, says Professor Mendelson, this was "Madison under pressure." This was not what he really thought. What he really thought was that the omission of a Bill of Rights from the original document was not "a material defect" and that supplyimg one would do little good because "experience proves" its "inefficiency on those occasions when its controul is most needed." Madison, Professor Mendelson tells us, "was unenthusiastic

35 Dennis v. United States, 341 U.S. 494 (1951).

36 Scales v. United States, 367 U.S. 203 (1961).

3764 Stat. 987, 50 U.S.C. $\$ \S 781-98$ (1958). See Communist Party v. Subversive Activitics Control Bd., 367 U.S. 1 (1961).

38 Frantz, supra note 2, at 1448.

391 ANNAIS OF CoNgress 457 (1789). 
about the Bill-of-Rights-Judicial-Review approach because he foresaw a far more reliable, and far more sophisticated, shield for civil liberty: the structure and process of politics." 40

Madison also wrote:

[I] n a representative republic, where the executive magistracy is carefully hmited; both in the extent and the duration of its power; and where the legislative power is exercised by an assembly, which is inspired, by a supposed influence over the people, with an intrepid confidence in its own strength; which is sufficiently numerous to feel all the passions which actutate a inultitude, yet not so numerous as to be incapable of pursuing the objects of its passions, by means which reason prescribes; it is against the enterprising ambition of this department that the people ought to indulge all their jealousy and exhaust all their precautions. ${ }^{41}$

It is hard to believe that the author of these lines was an early prophet of the view that there should be no limits to the powers of the Congress except those automatically imposed by "the structure and process of politics."

And if he was, what of it? The issue is not what Madison really thought, but low the first amendment was presented to those who voted for its enactment. If Madison thouglit that the document lie proposed was not really needed and would prove ineffective, then the Congress that adopted his proposal, and the states that ratified it, overruled him in that respect and his true opinion can no longer be put into effect, except by further recourse to the amending process.

Professor Mendelson notes that I criticized the Court "for not enforcing the first amendment as 'absolutely' as it enforces soine other Bill-ofRiglits provisions." To this he responds:

The answer is presumably that these other provisions are directed largely against judges, administrators, and police officers. It is one thing for the Supreme Court to override them; it is quite another to override the National Legislature acting in its lawmaking capacity. ${ }^{42}$

So it seems to be contended that the first amendment ought to be assigned a constitutional status inferior to the rest of the Bill of Rights. A provision that undertakes to limit the powers of the national legislature is more unwise than one whicl merely addresses itself to the powers of judges, administrators, and police officers. It ought to be accorded less enforcement. ${ }^{43}$ It is mdeed a serious matter to limit the powers of Congress "acting

40 Mendelson, supra note 1 , at 827 .

41 The FederaIIST No. 48, at 339-40 (Dunne ect. 1901) (Madison).

42 Mendelson, supra note 1 , at $828 \mathrm{n} .38$ (Italics in original).

43 Professor Mendelson seems to go beyond Justice Frankfurter on this point. Compare: "As no constitutional guarantee enjoys preference, so none sbould suffer subordination or deletion .... . To view a particular provision of the Bill of Rights with disfavor inevitably results in a constricted application of it. This is to disrespect the Constitution." Ullman v. Umited States, 350 U.S. 422, 428-29 (1956). 
in its lawmaking capacity." It might, however, be even more serious for the power of Congress, especially in this area, to be subject to no limits except those under its own control. The framers may well have been aware of the seriousness of both when they wrote "Congress shall make no law ...."

And, while it is not necessary to my present argument to contend that the courts should discriminate for or against any constitutional provision, surely it is obvious that, if such a discrimination were to be made, the opposite discrimination would be far more justifiable than that which Professor Mendelson suggests. The question of the proper relationship and division of competence between representative government and the people represented goes to the fundamental nature and purpose of the constitutional plan and is thus of a higher level of importance than even such matters as the fundamentals of fair trial. ${ }^{44}$ Furthermore, it would be far more tolerable to give Congress the last word on what the Constitution means when it puts restraints on judges, administrators, and police officers than to give Congress the last word on the constitutional limits of its own powers.

Professor Mendelson persistently reminds us of the "activists" of the old Court, who read essentially economic judgments into the Constitution by means of "substantive due process" and "liberty of contract." Presentday hbertarian "activists," such as Justice Black, are, he insists, making the same mistake. ${ }^{45} \mathrm{He}$ insists that judicial enforcement of the first amendment is not distinguishable from "substantive due process" because, in both cases, the judgment of individual justices must intervene between the constitutional generalization and the particular result. ${ }^{40}$ But the matter cannot be reduced to presence or absence of judgment. There is also a consideration of how much judgment, what kind of judgment, and the degree to which the judgment is related to the constitutional text and to a defensible concept of its probable purpose.

44 Of course, the mere fact that a constitutional provision is important does not, per se, prove that judicial enforcement is more desirable than some other means. It does, I think, strongly suggest that judicial enforcement ought not to be weakened unless we are certain that effective alternative means of enforcement are available. And it suggests also that the courts, if they assume the responsibility of construing and applying a provision of such importance ought not to do it in a diffident and grudging manner.

45 Mendelson, supra note 1, at 824-28. See also Menderson, Justices Brack AND FrantFURTER: CONFLICT IN THE COURT (1961), especially at pp. 124-31.

46 Apologists for the modern version of activist Justice seem to concentrate upon its First Amendment aspects and ignore its economic implications. . . . This permits them to rest upon-or hide behmd-the hallowed generalities of democratic dogma. Even so, they do not argue that the Constitution guarantees absolute freedom of expression, or that any explicit limitation can be found in the written document. Choice then is inevitable. Yet we are not told why a legislative choice between competing interests here is, $a$ priori, less worth of respect than elsewhere.

Id. at 119-20 (Italics in original). 
The due process clause reads "No person shall be ... deprived of life, liberty, or property, without due process of law." A judge who decides that an economic regulation is "not due process" because it abridges a liberty he thinks ought not to be abridged, has not construed the key term "due process." He has read it out. He has made the amendment read: "no person shall be deprived of [this kind of] liberty [by any process whatsoever]." Purely as a matter of judicial "activism" or "restraint," and leaving out all other considerations, this is an entirely different type of judgment than one that occurs when a court draws from the language of the freedom of speech clause an mference that, though the language may not make it inescapable, is nevertheless within the language, related to a defensible concept of its probable purpose, and which is ineseapably the kind of inference that the court must make if it is to give the language any effect.

Professor Mendelson writes that "surely a judicial veto of anti-communist legislation limits the range of popular choice just as effectively as a judicial veto of minimum wage legislation. Both say to the people these are choices you may not make." 47 It is difficult to see why a process for amending the Constitution was thought necessary, unless it was conceived that there were some choices that might not be made, except by that process. However, these two kinds of "judicial veto" are not at all counparable in ternis of their effect on "popular choice." The "judicial veto" of wage legislation says to the people: "Your present opimion may not be implemented because it is wrong." The "judicial veto" of anti-communist legislation says to the people: "Your present opinion may be implemented in many ways, but it may not be put beyond the possibility of criticism and reconsideration. Your freedom to choose is very broad. But the choice of abolishing your own future freedom of choice is one that you may not niake, except by constitutional amendment."

If a judgment made by a majority of both Houses of Congress and concurred in by the President is entitled to great judicial deference, then is not some deference also due to a judgment made by two-thirds of both Houses and ratified by three-fourths of the states? If my contention that the first amendinent was adopted with the expectation and intention that it would be enforced by the courts is conceded, then (whether or not its adoption was a mistake) any "judicial activism" inherent in giving effect to that intention is merely the carrying out of a role that the Court has been assigned by constitutional processes.

Furthermore, if the premise be conceded, it is literally impossible for the Court to escape from that role to a less "activist" one. If it is "activist" for the judge to mediate between the general proposition written into the 
Constitution and the specific problem presented by the particular case, it cannot be less "activist" for him to deny the drafters and ratifiers any voice in the matter by putting the text aside so that the Court can determine, on a pragmatic case-to-case basis uninhibited by constitutional principles, what the particular results should be. The only third alternative is to decide not to decide. But that (if my premise be conceded) is the most "activist" choice of all. If it is "activist" to put a statute aside on the ground that it is contrary to what the Court conceives to be the meaning of the Constitution, surely it cannot be "restraint" to put a constitutional provision aside on the ground that it is contrary to what the Court conceives to be sound political theory.

And while we are remembering the "activism" of the old Court, let us not forget what happened when President Franklin D. Roosevelt tried to find an institutional remedy for it. The Congressmen found that their mail from home ran heavily against the proposal, though it was one which fell far short of stripping the Court of its powers. ${ }^{48}$ So the best indication that we have of the popular will with regard to judicial review is that the people would rather risk temporary frustration of their will by myopic decisions than risk a government that no longer has to submit its actions to an independent determination of their constitutional validity. And this choice was made at a moment when the Court was not only overruling an overwhelmingly popular program on exceedingly questionable constitutional grounds, but also making it difficult for the nation to find effective remedies for the great depression.

So it would seem that the Court has no popular mandate, formal or informal, to behave in the way Professor Mendelson thinks it ought to belrave. A constitutional amendment leaving the first amendment in force as an admonition to Congress, but denying the courts the power to enforce it by declaring acts of Congress unconstitutional, would not be difficult to draft. Those who think this is the right arrangement should draft such an amendment and submit it to the ratification process. ${ }^{40}$ Let us not, in the

48 The flood of letters and telegrams received when the plan was first proposed is said to have run 9 to 1 against the proposal. Axsop \& CATLEDGE, THE 168 DAYS 72 (1938). Even if a considerable part of this is discounted, as possibly having been drummed up by persons wishing to exploit the issue for other purposes, the dramatic contrast with the overwhelming popularity of the President and his program just demonstrated at the polls remains highly significant.

40 Our forefathers, when they wrote this provision [against compulsory self-incrimination] into the Fifth Amendment of the Constitution ... made a judgment and expressed it in our fundamental law .... If it be thought that the privilege is outmoded in the conditions of this modern age, then the thing to do is to take it out of the Constitution, not to whittle it down by the subtle encroachments of judicial opinion.

Ullmann v. Umited States, 350 U.S. 422, 427-28 (1956) (Frankfurter, J.) (quoting Maffie v. United States, 209 F.2d 225, 227 (1st Cir. 1954)). 
name of "judicial restraint," attempt to convince the judges that the present constitutional arrangeinent is wrong and they should therefore change it by refusing to discharge the function assigned them, or by reading an amendment beginning "Congress shall make no law" as imposing no significant limitation on Congress's freedom to make laws.

Professor Mendelson's contentions seem to go far beyond even this, if I understand hin correctly. In answer to the "anguished question" which he thinks I put, at least by inplication-what good is the first amendment if it is construed as the balancing test construes it?-he observes: "Madison long ago gave the answer: It is futile to rely on judges and 'parchment barriers'; politics is the only reliable protection for basic substantive interests." 50 And he continues, paraphrasing Madison:

For him the constitutional diffusion of power and the vast expanse of the nation with its multiplicity of regional, economic, religious, and other interests were the true safeguards. ... Government could act only after political compromise liad found the common denominator of a host of unutually suspicious minorities. ... No program that had survived the give and take necessary to obtain support by a concurrent majority of our incredibly varied factional interests could depart substantially from the Nation's moral center of gravity. No governmental system could be expected to achieve more; certainly not by idealistic fiats from the Bench that fly in the face of deeply felt community needs. In short, as Madison saw it, majority rule-given a vast empire of diffused socio-political power-was the only reliable safeguard against governmental inhumanity. ${ }^{51}$

Whether this was Madison's answer or not, any contention that it is a sufficient answer goes far beyond the issue of first amendment balancing, and even far beyond the issue of judicial review. It amounts to saying that the whole idea of a government of limited powers, deriving its powers froin a written constitution and holding thein subject to limitations prescribed in that charter, is simply wrong.

I am aware, of course, that the British enjoy considerable freedom under a system of legislative supremacy, and without legally enforceable limits on the powers of Parliament. Yet it seems to me that all that needs to be said about the British system in this connection is: we cannot possibly get to it from where we are. The special virtues of the British system cannot be achieved merely by absence of a written constitution, or refusal to apply one. Renouncing our whole constitutional heritage as merely a set of futile "parchment barriers," and announcing that henceforth there are

s0 Mendelson, supra note 1, at 826. Professor Mendelson's version of my "anguished question" is: "What good is the first amendment, if it is not to be given a 'preferred place' by 'activist' magistrates?" Since the question is attributed to me, I have taken the liberty of rephrasing it.

51 Id. at $827-28$. 
to be no limits except such as "politics" itself may set, will not give us the special virtues of the British system-it will merely destroy the special virtues of our own without giving us anything to take their place.

In any case, if some of us are now convinced that legislative supremacy is the true principle, surely that view ought to be presented to Congress and the people as the basis for a new constitutional convention. This is not an argument to be presented to the justices as the proper theory for them to apply in construing a Constitution not based upon it. Let us not, in the name of "judicial restraint," ask the judges to carry out a major constitutional revolution without consulting the people.

\section{III}

\section{DOES THE CASE AGAINST JUDICIAL REVIEW JUSTIFY} $A D$ HOC BALANCING?

Professor Mendelson's argument that the judges ought not to decide seems to me curiously at odds with the doctrine lie set out to defend. If his whole argument were accepted, the most that could follow would be that the Court should declare: "Whether this is consistent with the first amendment is not for us to say. The fact that Congress has passed it implies a congressional judgment that it is. From that judgment there is no appeal, except to the electorate." I have already indicated my reasons for finding this unacceptable. But, acceptable or not, it is a far cry from the balancing test, which says: "If this action is needed, then the mere fact of that need makes it constitutional. This Court [still the Constitution's authoritative spokesman] so holds." There is a vast difference between these two statements, and I submit that the latter is far more unfavorable to freedom of speech than the former. Under the balancing test, Congress gets whatever power it wants, but is expressly relieved of constitutional responsibility. The Court takes the responsibility, but without any basis for exercising an independent judgment. Congress can say to the voters: "We not only chastised the heretic and discouraged the heresy, but we did it without violating the first amendment. We have a certificate from the Constitution's authoritative spokesman that this is the case. And this certificate is also a precedent which establishes that whenever we think it necessary to take other similar actions in the future, it will be constitutionally right and permissible for us to do so."

Even Professor Mendelson, following Learned Hand, appears to concede that the first amendment ought to stand as an admointion to Congress. ${ }^{\tilde{2}}$ But the amendment, as read by the balancing test, tells Congress only: "Don't abridge freedom of speech, unless you think it needs to be 
abridged." This merely amounts to: "Don't abridge freedom of speech any more than you would have thought proper if the Constitution had made no provision on the subject." Where is the admonition?

Professor Mendelson tells us, with apparent approval, that Madison

insisted that the only use of a formal declaration [of rights] was that "the political truths declared in that solemn manner acquire by degrees the character of fundamental maxims of free government, and as they become incorporated with the national sentiment, counteract the impulses of interest and passion." If the government should act improperly, a bill of rights would be "a good ground for an appeal to the sense of the community." 53

Is "don't abridge freedom of speech except when it needs to be abridged" one of the "fundamental maxims of free government"? If this version of the first amendment's meaning becomes "incorporated with the national sentiment," will it "counteract the impulses of interest and passion"? Will it not, rather, explicitly invite "interest and passion" to do their will?

I tend to agree with Professor Mendelson that relatively too much of the libertarian effort in this country has been and is focused on the constitutional struggle in the courts, and that the proportion of that effort that has gone into educating the people on the meaming and value of their constitutional heritage has been far too small. But that does not mean that a choice must be made between the two methods. Both can be used simultaneously and eacli can stimulate and reinforce the other.

What Professor Mendelson's argument completely ignores is that the Court's official declaration that a controversial action is or is not constitutional necessarily injects into the legislative process and the political process a judgment that will be accorded enormous moral weiglit and will greatly affect the outcome of these processes. His failure to see this is slown by his statement that the School Segregation decision ${ }^{54}$ was "costly indeed, if it convinced libertarians that the judicial process is an effective tool of libertariamism." ing that the percentage of compliance with the decision is still low. ${ }^{58}$

Yet would anyone deny that both the Negro demand for full equality and white acceptance of that demand have risen further and faster since that decision than at any time since Reconstruction? Would anyone deny that a considerable, though not measurable, part of that tempo was due to the impetus provided by the Supreme Court's decision that this country

53 Ibid.

54 Brown v. Bd. of Education, 347 U.S. 483 (1954).

65 Mendelson, sttpra note 1 , at 828 n.39.

56 This argument, of course, ignores the fact that any integration in the South, even "token" integration, is an enormous step forward. In fact, it is quite possibly the largest single step along the whole road-and the one hardest to take. 
had a constitutional commitment to racial equality and that segregation was in violation of that commitment? Suppose the Court had reaffirmed Plessy v. Ferguson ${ }^{57}$ and held that compulsory segregation is constitutional whenever "equal" facilities are provided. Can anyone doubt that such a decision would have been a grievous blow to the fight for racial equality, not just in the courts, but also in the legislative halls, at the ballot box, and at every conceivable level?

This powerful role of the judicial judgment in the political process itself cannot be eliminated by "judicial restraint." It can be eliminated only if the Court's function of construing the Constitution is expressly and openly abohished, so that no failure to say "This is unconstitutional" can be construed as a judgment to the contrary. The type of "judicial restraint" represented by the balancing test injects into the political process an authoritative declaration from the Constitution's official spokesman, saying, in effect: "This country has no constitutional commitment to freedom of dissent. True, we ordinarily permit it-but that is only because ordinarily there is no sufficient reason not to. Whenever such a reason arises, it is perfectly constitutional to set that freedom aside."

No argument that the courts ought not to decide, and that libertarians should take their case to the people instead of to the courts, can justify this result.

\section{IV}

\section{DOES $A D$ HOC BALANCING GIVE A BETTER ACCOUNT OF HOW THE DECISION WAS REACHED?}

Professor Mendelson writes:

Open balancing compels a judge to take full responsibility for his decisions, and promises a particularized, rational account of how he arrives at them-more particularized and more rational at least than the familiar parade of hallowed abstractions, elastic absolutes and selective history. Moreover, this approach should make it more difficult for judges to rest on their predispositions without ever subjecting them to the test of reason. It should also make their accounts more rationally auditable. ${ }^{58}$

He does not tell us how or why "open balancing" will have these results. He just asserts that it will. I am not convinced.

Let us take a balancing case. The House Committee on Un-American Activities has heard testimony from a Mr. Crowley that Mr. Barenblatt, during a period ending some four years previously, had been a Communist while he was a student and teaching fellow at the state university. The Committee summons Mr. Barenblatt, demands to know whether he is or 
has ever been a Communist, and he refuses to answer. ${ }^{59}$ What are the "interests" on either side that the Court must "balance"?

On the government's side, it might be the Committee's interest in verifying Mr. Crowley's testimony, or its desire for more sources of imformation, or its desire to put any one of several possible messages before the public, or its desire for unobstructed freedom in deterumining what it ought to investigate, or its desire to punish a contumacious witness, or to discourage contumacy in future witnesses, or to vindicate its own authority, or that of the Congress, or the individual's public obligation to give testimony. Or it might be the interest of Congress in being fully informed when it legislates, or the public interest in having legislation based on full information, or the national interest in being fully informed on the nature and extent of communist activities, or the nation's (or democracy's, or humanity's) interest in the fight against communism (or against tyranny in general). Or it might be "national self-preservation."

Mr. Barenblatt's interest in remaining silent umght be his desire to withhold the information, or to protect his reputation and eniployability, or to protect the friends whom the Committee will require him to identify if he testifies fully, or his own right to choose his ideas and associates without governmental supervision, or to behave as his conscience dictates, or to vindicate the first amendnient, or freedom of speech and association, or freedom in general. Or it might be the public or national interest in freedom of discussion and association, or in maintaining the effectiveness of the first amendnient, or of constitutional limitations in general, or in discouraging arbitrary assaults on individual freedom. Or (on the theory that political freedom is safer than repression in the long run) "national selfpreservation" might belong on Mr. Barenblatt's side.

Which "interest" is the judge to balance against which? It is obvious that if he balances Mr. Barenblatt's personal interests against "national self-preservation" he will get one result. If he balances the Committee's desire to verify Mr. Crowley's testimony against freedom of speech, and also assumes that an important public imterest is at stake in the latter, he will get another. So it appears to be very difficult for him to identify the "interests" without predetermining the result. The difficulty is emphasized by the ease with which Justice Black, while continuing to protest "balancing," demonstrates that, for him, it would produce an opposite result. ${ }^{60} \mathrm{He}$ simply trims the asserted governmental interest to more moderate size, puts a more generalized (and therefore weightier) free speech interest on

50 Barenblatt v. United States, 360 U.S. 109 (1959).

C0 Lathrop v. Donohue, 367 U.S. 820, 874 (1961) (dissenting opinion); Konigsberg v. State Bar, 366 U.S. 36, 71 (1961) (dissenting opinion); Barenblatt v. United States, 360 U.S. 109, 144 (1959) (dissenting opinion). 
the other side of the scales, and there you are. Anyone can do it. And anyone can reverse it just as easily by the opposite process.

How is the judge to convert balancing into something that does not merely give him back whatever answer he feeds into it? Presumably, he should generalize one interest exactly as much as the other, but how can he be sure he has done so? He might take a particularized view of the interests on both sides. ${ }^{61}$ Surely lie will not, in that case, do justice to the interests on either side. There is a great deal more at stake on both sides than the desire of the particular litigants to obtain a particular result. ${ }^{62}$ Yet how can he state what more is involved without assuming, in some form or other, that a principle is at stake? If he does that, he is back in the very situation from which "balancing" was supposed to extricate him - except that he can cloose his principles as lie pleases, without reference to the Constitution.

Suppose the judge has solved this conundrum, or managed not to see it. He has now identified the "interests." He next has to "weigh" them. But they are not quantitative and therefore they cannot, except in a vague metaphorical sense, be "weighed" at all. What does the metaphor mean? If the judge determines merely the intensity with which the particular litigant desires the particular result, he is once more ignoring the fact that there is really more at stake than that. And obviously, both litigants desire the result with considerable vigor, or they would not be in the Supreme Court. Yet on what basis is it possible to say that one interest "weighs" more or less than the intensity which wlich it is desired-unless the judge can refer to some principle that tells hin that some claims are more legitimate, or more important, than others? If there is such a principle, would not the judge give us a better account of lis process of decision if he told us what he conceives the principle to be, and low it relates to the Constitution, and why lie thinks the facts present it-instead of using it as an unstated premise for regarding one "interest" as "weightier" than another?

As soon as he finishes measuring the unmeasurable, the judge's next job is to compare the incomparable. Even if he has succeeded in stating the

61 This is apparently what the majority opinion in Barenblatt set out to do, simce it states that "The [Congressional] power [of inquiry] and the right of resistance to it are to be judged in the concrete, not on the basis of abstractions." Barenblatt v. United States, 360 U.S. 109, 112 (1959). Yet, in the very next sentence, the interest on one side is converted into "a nationwide, indeed world-wide, problem." Ibid. Needless to say, the interest on the other side continues to be viewed as "private," $i d$. at 126 , and "individual," $i d$. at 134, though it would be by no means impossible to regard protection of the individual against the constantly growing power of government as a nation-wide and even world-wide problen. Compare United States v. Raines, 362 U.S. 17, 27 (1960) ("[T] )ere is the highest public interest in the due observance of all the constitutional guarantees, including those that bear most directly on private rights ...."). Evidently using "balancing" for any other purpose than to rationalize a result reached in some other way is easier said than done.

62 Fried, Two Concepts of Interests: Some Reflections on the Supreme Court's Balancing Test, 76 HARV. L. REv. 755 (1963). 
interests quantitatively (or thinks he has), they are still interests of different kinds and therefore they can no more be compared quantitatively than sheep can be subtracted from goats. It is literally impossible for him to compare them unless he has some standard independent of both to which they can be referred. What is that standard to be? Is it to be the Constitution? If so, what did the judge gain by abandoning the Constitution for a long process of reasoming that merely led him back to it? And, if not the Constitution, then what is to it be?

I cannot join Professor Mendelson in finding in this process any promise that the real basis of decision will be more fully disclosed. On the contrary, it seems to me to make the real basis of the decision inore difficult to identify than the economic "activists" of the old Court, at their worst, ever made it. Nor do I find in the cases that purport to have been decided by this process anything that will enable a lawyer to advise his client of his rights. ${ }^{63}$

Does such a process make it "more difficult for judges to rest on their predispositions without ever subjecting them to the test of reason"? That ad hoc balancing does just the opposite seems to me so painfully obvious that $I$ am almost at a loss how to argue it. What is there that can assure, or even promote, impartiality of results, if there is no rule that can be impartially applied? I do not understand how impartiality can even be conceived without assuming the existence of such a rule. Even if we assume that "balancing" is capable of giving impartial results (whicll seems to me very unlikely), how can the losing litigant look at balancing language and feel any assurance that the judge succeeded in keeping his personal preferences out of his "scales"? How can the public do so? How can the judge himself do so? ${ }^{64}$

03 Only a few years ago, we were assured that the Court's past decisions in this area "establish sure guides to decision." Barenblatt v. United States, 360 U.S. 109, 126 (1959). Now it seems they merely "illumine the contending principles." Gibson v. Florida Investigating Comm., 372 U.S. 539, 543 (1963).

64 In a recent case, N.A.A.C.P. v. Button, 371 U.S. 415 (1963), both the Court's opinion, id. at $444-45$, and the dissent, $i d$. at 448 , go out of their way to state that the Court does not regard the right to freedon of speech as entitled to any higher constitutional protection in cases where racial equality is being advocated. I do not question the sucerity of these protestations, but surely they ought not to have been necessary-and would not have been if the Court, instead of engaging in ad hoc balancing, had enunciated and apphed impartial rules, by which the rights of all could be measured. Compare Mr. Justice Jackson's observation on the

treacherous grounds we tread when we undertake to translate ethical concepts into legal ones, case by case. We usually end up by condemning all that we personally disapprove and for no better reason than that we disapprove it. In fact, what better rcason is there? Uniformity and equal protection of the laws can come only from a statutory definition of rairly stable and confined bounds.

Jordan v. DeGeorge, 341 U.S. 223, 242 (1951) (dissenting opimion). This would seen $a$ fortiori true of ad hoc balancing, which leaves the judge to seek pragmatically desirable results case by case without even the guidance of an ethical concept. 
DOES THE CRITICISM OF "ABSOLUTES" JUSTIFY

\section{$A D$ HOC BALANCING?}

As anyone can verify by consulting the nearest dictionary, the word "absolute" has several quite different recognized meanings. Accordingly, putting the issue in the form, "is the freedom of speech absolute?" or "is the first amendment an absolute?" is unlikely to result in anything but confusion and failure to communicate unless some further effort is made to specify precisely what is meant by the question. Confusion and failure to communicate are, in iny opinion, what we have chiefly been having $\mathrm{m}$ this area.

"Absolute" might inean: without limits. And some people seem seriously to regard the first amendment "absolutists" as guilty of some inconsistency because they do not insist that first amendment protection is infinite in scope. $^{65}$ A legal rule that was "absolute" in this sense would control all possible cases. No case, however remote, could be excluded from it without giving the rule a limit and thereby destroying its "absoluteness." Such a rule would eliminate the possibility of having any other rule. It would also be meaningless, since we could not give it meaming without defining it and to define is to set limits. It is not difficult to demonstrate that the first amendment is not "absolute" in this sense, but to do so is to knock down a straw man. No one contends, or ever has contended, that it is.

"Absolute" might mean: not open to exceptions. This seems to be approximately what most of the "anti-absolutists" have in mind-though I have yet to find one who specifies clearly what he does have in mind. The argument that takes this form requires that it be either expressly or tacitly assumed that "the freedom of speech" means each individual's right to say anything he pleases, on any subject, at any time, in any manner he pleases, and regardless of the circumstances. The next step is to show instances in which the "freedom" thus defined would have to be abridged. This is taken to demonstrate that "the freedom of speech" is "not absolute." Accordingly, when the government undertakes to regulate the content of public debate, it is insisted that, since "the freedom of speech" is not "absolute," the first amendment cannot be regarded as containing any "dogmatic" as-

65 The very justices who assert that the prohibitions in the Bill of Rights are absolute, brooking no restrictions of the freedoin they protect, have in fact voted to restrict the same freedoms on inore than one occasion. A favorite judicial technique in such cases is to define one's absolute so that its protective scope does not cover the interests before the Court.

Karst, Legislative Facts in Constitutional Adjudication, 1960 SuPreme CouRT REv. 75, 78-79 (Kurland ed.). I do not know what Professor Mendelson ineans by his disparaging reference to "elastic absolutes" (text acconipanying note 58 supra), unless this also imphes that the only true and respectable "absolute" is one which is conpletely undefined and has no limits. 
sertion that the government has no such power. There is thus nothing to do but to "balance," to determine on an ad hoc pragmatic basis whether the particular regulation seems justified under the particular circumstances.

Even if this meaning of "the freedom of speech" is accepted, arguendo, it is simply a non-sequitur to argue that "balancing" is therefore inescapable. If a legal rule has been stated too broadly and unstated exceptions must therefore be read into it, it does not necessarily follow that it is therefore open to any and all exceptions that the decision-maker wants to make, without regard to whether they are consistent or inconsistent with the function and purpose of the main rule.

Government can and must exercise a great deal of control over radio, yet no one supposes that it necessarily follows that there would be no impropriety in a regulation allowing Democrats to broadcast, but not Repubhicans, or leaving the airways open to those who wish to praise government policy, but not to those who wish to criticize. The chairman of a meeting, if business is to be transacted, must exercise considerable control over "the freedom of speech" of those present, so I suppose it must be conceded that that "freedom" is "not absolute." It does not follow that the chairman would not be abusing his powers if he permitted speech in favor of the motion, but not speech against it, or vice versa. I am not suggesting, of course, that the proper reading of the first amendment could be derived from either of these very imprecise analogies. The point is simply that, from "some regulation is inescapable," it just does not follow that "therefore no regulation of any particular kind can be regarded as in principle impermissible." It is this non-sequitur that the sloganizing against first amendment "absolutes" serves to conceal.

Furthermore, the whole argument falls without the initial premise that "the freedom of speech" means, as Justice Harlan put it, "an unlimited license to talk." It is only on the basis of this premise that the "freedom" has been shown to be "not absolute." So the whole argument proves nothing unless it can first be demonstrated that the freedom of speech clause is not capable of any meaning that could be consistently applied. The first amendment non-absolutists have not undertaken any such demonstration. They have not even bothered to explore what other meanings are possible. It is nuuch too convenient to rest on "the first amendment is not an absolute," without any close inquiry as to what such a statement might nean, thus leaving the way open to put first amendment freedonis aside whenever we think they should be put aside-or, to put it bluntly, whenever we want to do so.

So the statement that the first amendment is "not an absolute" (though I would agree that it is true, not merely in one sense, but in several of its 
possible senses) does not seem to me capable, at least without further analysis, of shedding much light on the problem to which it purports to be addressed. For a further demonstration of this, let us experiment with putting the same question in a different form. Instead of asking, "Is the first amendment an absolute?" let us ask, "Are there any limits to the powers of our national legislature, assuming that it lias been democratically elected and that its efforts have majority support?" Now it is Justice Black who is saying that those powers are very broad indeed, but they are not absolute, since the Constitution sets limits. Now it is Professor Mendelson who is insisting that the principle of "majority rule" admits of neither limits nor exceptions-and comforting us with the thought that, in view of the clash of infinitely varied interests across our vast expanse of territory, it will never liave need of either limits or exceptions. Who is the "absolutist" now? If the Justice is open to a charge of employing "absolutes," his critic is no less so-he simply employs a different one. It might even be thought that Professor Mendelson's "absolute" is a good deal broader and more sweeping than Justice Black's-that absolute limits on power, even if sometimes inconvenient, are rather less to be feared than absolute power, even if the latter is founded on the premise of majority will. In any case, there must be some better way of choosing between these points of view than labeling the Justice's position "absolutist," thus subjecting it to a purely verbal criticism that can be turned the other way merely by inverting the form of the question.

"Absolute" might mean: mandatory. It might, in other words, be a judgment addressed, not to the meaning and scope of the constitutional proposition, but simply to its obligatory character once that meaning and scope have been determined.

Much of what is frequently decried as a deniand for "absolutes" seems to me nothing nore than a demand that the Court should ask itself first, "Is this the type of governmental action that the first amendment forbids?" And, if it thinks that question requires an affirmative answer, it should say: "We cannot give nore deference to a legislative judgment that this is needed (whether or not we agree) than we give to a constitutional judgment, reached by a more solemn and binding process, that the power to do it is a dangerous one which the government ought not to have. The exact content of the latter judgment is not always certain, but it is there and we must apply it as best we can. Whatever it forbids can be authorized only by the same process by which it was forbidden, i.e., by constitutional amendment." If this is employing "absolutes," then it is also employing "absolutes" for a court to choose between two possible constructions of a statute and then say: "If this is wliat the legislature meant, as we think it is, then our judgment as to whether it is desirable is beside the point. Our 
job is to apply the statute, not to reach an $a d$ hoc result based on the same considerations we might have applied had it never been written."

If either of these is employing "absolutes," then "absolutes" are the day to day stuff of adjudication. Indeed, if it is impossible or impermissible for a court to apply such "absolutes," then it would seem that Professor Mendelson's candidates for supremacy, the statute-writers, are, no less than the constitution-makers, engaged in a very fruitless occupation.

Much of what is phrased in the form of a demand for the rejection of "absolutes" seeins to me a demand that the question "Is this desirable?" should not only be asked first, but should be the sole determinative factor in the final result. Only after the decision has been made is the first amendment to be called in and required to give its constitutional blessing, willy nilly, to a decision in which it played no part. If this is what the demand for a rejection of "absolutes" means, it is simply a demand that the first amendment should not be treated as a constitutional limitation.

Nor do I think that the philosophical proposition that "there are no absolutes," as though it were something like a folding chair, subject to be collapsed at will whenever it might otherwise be in the way. John Stuart Mill long ago observed that repressing any opinion is always an assumption of infallibility. ${ }^{\text {es }}$ This seems to me a wise observation. An assumption of infallibility is a strange result to justify on the basis of a philosophical observation that all things are relative. If we wish to apply the philosophical observation to the free speech issue, I would suggest we begin with the proposition that our present normative judgments about how society ought to be organized, and what is correct political theory, and what governmental policy ought to be, are "not absolute" - and therefore we should keep them open, as "absolutely" as we can, to continuous criticism and re-examination. ${ }^{68}$

\section{VI}

IS THE AMERICAN CITIZEN "A POLITICAL, NOT A LEGAL, ANIMAL?"

Professor Mendelson concludes his article with the observation:

Sooner or later libertarians will have to face it - the real victories are won in legislatures and at the polls. Man after all is a political, not a legal, animal. ${ }^{70}$

67 Dennis v. United States, 341 U.S. 494, 508 (1951).

$68 \mathrm{MIII}$, ON LIBERTY 21-22 (Library of Liberal Arts ed. 1956).

${ }^{69}$ See Comment, The Constitutional Right to Anonymity: Free Speech, Disclosure and the Devil, 70 YaIE L.J. 1084, 1116-21 (1961).

70 Mendelson, supra note 1 , at 828. 
I cannot agree. It seems to me that if you look at any society, even the most primitive, you will find some kind of law. It may be traditional, unwritten, and attributed to supernatural sources, but it is law nonetheless. So it seems probable that law is about as old as society. Politics is, by comparison, quite a recent invention.

Furthermore, most of the specimens with which $I$ am acquainted do not show the primacy of the political impulse that Professor Mendelson attributes to the species. Indeed, I had thought it was one of the most serious problems of our form of government that it seems to need a citizen who has somehow been trained or inspired to be much more political than he has any innate inclination to be. Most of my friends and neighbors resort to politics only sporadically and reluctantly. When the crisis or election is over, they relapse into political inactivity with an ease and naturalness that suggests that the latter is their more natural mode of existence. Yet I think they demand law-and moral standards capable of identifying something more than a mere conflict of interests in the choices to be made-as the limiting framework and guidelines of everyday living, because without them life in society would be intolerable. I do not think they will willingly settle for the view that justice is the interest of the stronger-even if stronger means politically stronger.

Finally, the American citizen is heir to a British struggle to set limits on governmental power which goes back to the "Glorious Revolution" of 1689 , to the Puritan Revolution which preceded it, and even to that episode, seven and a half centuries ago, when the barons wrung from Kmg John promises that he would not use power in certain ways, promises that came to be called the Magua Charta. And the American citizen's own immediate forebears on this side of the ocean have spent the better part of two centuries trying to translate the British "the king is under law" into "the government is under the Constitution and the Constitution is law." It is a bit breathtaking to be told, in effect, that this was all a mistake, that it is only the government's will that should be limited, not its powers, and that even its will should not be limited by anything other than the difficulty of finding a majority consensus annong a myriad of conflicting interests.

The problem of "rights" is, after all, just the reverse side of the problem of power. And the meaning of the doctrine that there are no rights, but only "interests," is that power has no limits. 